\title{
Incidence and clinical characteristics of thyroid abnormalities in cancer patients treated with immune checkpoint inhibitors
}

\author{
Dalia Cuenca, ${ }^{1}$ Elina Rodríguez-Meléndez, ${ }^{2}$ Mercedes Aguilar-Soto, ${ }^{1}$ Alain Sánchez-Rodríguez, ${ }^{1}$ \\ Nicole Íñiguez-Ariza, ${ }^{3}$ Guillermo Olivares-Beltrán, ${ }^{4}$ Raquel Gerson-Cwilich ${ }^{4}$ and Moisés Mercado ${ }^{5 *}$ \\ ${ }^{1}$ Department of Medicine, American British Cowdray Medical Center; 'Department of Medical Oncology, Hospital "Luis Vernaza y Solca", Guayaquil, \\ Ecuador; ${ }^{3}$ Department of Endocrinology and Metabolism, Instituto Nacional de Ciencias Médicas y Nutrición "Salvador Zubirán"; ${ }^{4}$ Cancer Center, \\ American British Cowdray Medical Center; ${ }^{5}$ Specialty Hospital, Centro Médico Nacional Siglo XXI, Instituto Mexicano del Seguro Social. $1,3-5$ Mexico \\ City, Mexico
}

\begin{abstract}
Introduction: Immune checkpoint inhibitors (ICI) are a group of drugs that have been used in recent years for the treatment of advanced malignancies such as melanoma, non-small cell lung cancer and other tumors, significantly increasing survival. However, the use of $\mathrm{ICl}$ has been associated with an increased risk of autoimmune diseases, with endocrine organs, specifically the thyroid, being highly susceptible to this phenomenon. Objective: To describe the incidence and clinical characteristics of patients treated with $\mathrm{ICl}$ who develop thyroid disease. Methods: The medical records of all patients who received ICI treatment within the last three years were retrospectively reviewed, with those who developed thyroid abnormalities being identified. Results: The prevalence of thyroiditis was $7 \%$, with an incidence of $21.4 \%$ of patients-month. Median time for the development of thyroiditis was 63 days. Most patients had mild or moderate symptoms and did not require hospitalization, although all but one developed permanent hypothyroidism and required hormone replacement therapy with levothyroxine. Conclusions: Thyroid dysfunction secondary to immunotherapy is a common entity in our population. Clinical presentation is usually mild and does not require treatment discontinuation; however, due to the high incidence of these adverse events, non-oncology specialists must be familiar with the diagnosis and treatment of these alterations in order to provide multidisciplinary management.
\end{abstract}

KEY WORDS: Immune checkpoint inhibitors. Thyroiditis. Toxicity. Immunotherapy. Hypothyroidism.

\section{Incidencia y características clínicas de la enfermedad tiroidea en pacientes con neoplasias malignas tratados con inhibidores de punto de control inmunológico}

\section{Resumen}

Introducción: Los inhibidores del punto de control inmunológico (IPCi) son utilizados en los últimos años en el tratamiento de neoplasias malignas avanzadas, con ellos se ha logrado un aumento significativo de la supervivencia; sin embargo, su uso se ha asociado a incremento del riesgo de enfermedades autoinmunes. Objetivo: Describir la incidencia y las características clínicas de los pacientes tratados con IPCi que desarrollaron tiroidopatía. Métodos: Se revisaron retrospectivamente los expedientes de todos los pacientes que recibieron IPCi en los últimos tres años y se identificaron aquellos que desarrollaron anomalías tiroideas. Resultados: La prevalencia de tiroiditis fue de $7 \%$, con una incidencia de $21.4 \%$ pacientes $/$ mes. La mediana del tiempo para el desarrollo de tiroiditis fue de 63 días. La mayoría de los pacientes presentó síntomas leves o moderados y no requirió hospitalización, si bien todos menos uno desarrollaron hipotiroidismo permanente y requirieron tera-

Correspondence:

*Moisés Mercado

E-mail: moises.mercado@endocrinologia.org.mx
Gac Med Mex. 2021:157:293-297

Contents available at PubMed

www.gacetamedicademexico.com

0016-3813/@ 2021 Academia Nacional de Medicina de México, A.C.. Published by Permanyer. This is an open access article under the CC BY-NC-ND license (http://creativecommons.org/licenses/by-nc-nd/4.0/). 
pia de reemplazo hormonal con levotiroxina. Conclusiones: La disfunción tiroidea secundaria a inmunoterapia es una entidad común en nuestra población. El cuadro clínico suele ser leve y no requiere suspender el tratamiento; sin embargo, debido a la alta incidencia de este evento adverso, los médicos no oncólogos deben estar familiarizados con su diagnóstico y tratamiento, para brindar un manejo multidisciplinario.

PALABRAS CLAVE: Inhibidores del punto de control inmunológico. Tiroiditis. Toxicidad. Inmunoterapia. Hipotiroidismo.

\section{Introduction}

Recent knowledge on the role played by the immune system in the control of cell proliferation and the development of neoplasms has revolutionized modern oncology. ${ }^{1}$ Based on this knowledge, a new group of cancer drugs known as immune checkpoint inhibitors (ICI) has been developed in recent years. ICls are monoclonal antibodies that target small molecules on the surface of $T$ cells. These molecules, or immune checkpoints, are cytotoxic T-lymphocyte-associated antigen-4 (CTLA-4) and programmed death molecule 1 (PD-1) and its ligand (PD-L1). These proteins modulate T-cell function and play a crucial role in antitumor immunity. ${ }^{2}$ Currently, there are six ICls for the treatment of solid tumors: ipilimumab (anti-CTLA-4 antibody), nivolumab, and pembrolizumab (with anti-PD-1 activity), as well as atezolizumab, avelumab and durvalumab (which inhibit PD-L1). ${ }^{3}$ These drugs have increased the survival of patients with metastatic cancer. ${ }^{4,5}$

By inhibiting these molecules, treatment with $\mathrm{ICl}$ produces a considerable activation of the immune system and thereby an increase in its antitumor activity. This mechanism generates a state of hyper-immunity that alters self-tolerance mechanisms, which can produce autoimmune adverse events in different organs and systems. The endocrine system is particularly susceptible to this immune phenomenon and, therefore, hormonal deficiencies may exist. The thyroid gland is the most commonly affected organ, with hyper- and hypothyroidism being likely to occur. ${ }^{6}$ The pituitary is the second most affected gland by these drugs, although some series report that alterations of this gland are even more common than those of the thyroid gland. ${ }^{7,8}$ Less frequently, autoimmune diabetes mellitus and adrenalitis secondary to the use of $\mathrm{ICl}$ have been identified. ${ }^{9}$ In this study, we describe our experience in the diagnosis and treatment of thyroid dysfunction secondary to the treatment with $\mathrm{ICl}$.

\section{Methods}

A retrospective study was carried out, in which the clinical, biochemical and imaging characteristics of
122 patients who received treatment with ICls (ipilimumab, nivolumab and pembrolizumab) in a tertiary care private hospital in Mexico City, between January 2014 and December 2017, were described Patients with evidence of thyroid dysfunction secondary to $\mathrm{ICI}$ treatment were compared with patients who did not exhibit post-treatment hormonal alterations. Data were obtained from the electronic medical record and the protocol was approved by the local bioethics committee, in accordance with the principles of the Declaration of Helsinki.

Treatment with ICls was administered according to clinical practice guidelines, i.e., until disease progression or severe toxicity that limited their use was observed. ${ }^{10,11}$ The Immune Checkpoint Inhibitors-related Thyroid Dysfunction Classification, published by the National Cancer Institute, was used to classify patients with thyroid dysfunction:

- Grade 1, asymptomatic; no specific treatment is required.

- Grade 2, mild or moderate symptoms that limit activities of daily living.

- Grade 3, severe symptoms; assistance for basic self-care activities is required.

- Grade 4, life-threatening symptoms.

- Grade 5, disease implying death due to adverse effects. ${ }^{12}$

Measurement of thyroid stimulating hormone (TSH), free T4 and free T3 was carried out by electrochemiluminescence immunoassays (Elecsys ${ }^{\circledR}$, Cobas 8000 , Roche, Basel, Switzerland). The TSH immunoassay has a detection limit of $0.005 \mu \mathrm{IU} / \mathrm{mL}$ and intra- and inter-assay variation coefficients $<1 \%$. The free T4 immunoassay has a detection limit of $0.04 \mathrm{ng} / \mathrm{dL}$ and intra- and inter-assay variation coefficients $<10 \%$. The free T3 assay has a detection limit of $0.4 \mathrm{pmol} / \mathrm{L}$, with a variation coefficient $<10 \%$.

For statistical analysis, numerical variables are described as the mean and standard deviation or median and interquartile ranges, depending on their distribution. Categorical variables are described as percentages and frequencies. The prevalence and incidence of thyroiditis secondary to immunotherapy 
was estimated per 1,000 patients/month. Comparison of the clinical and biochemical characteristics of patients with and without thyroiditis was performed using Mann-Whitney's U-test or Student's t-test, according to the distribution, in the case of continuous variables, and by means of the chi-square test for categorical variables. A p-value $<0.05$ was considered to be statistically significant. For the analysis of categorical variables with multiple comparisons, Kruksal-Wallis test was used. Data were analyzed with the statistical programs JMP 15 and SPSS, version 23.

\section{Results}

During the study period, 122 patients with solid tumors at advanced stages were treated with ICls. Mean age was $61.95 \pm 13.4$ years, $40(35.7 \%)$ were females, and 113 (92.6\%) had clinical stage 4 disease. The most common tumors were non-small cell lung cancer $(36.8 \%)$, melanoma $(29.5 \%)$ and urothelial carcinoma of the bladder (19.6\%). Most patients $(50 \%)$ received pembrolizumab, which was followed by the use of nivolumab (33.6 \%) and ipilimumab (13.1 $\%)$; only four patients received combination therapy with ipilimumab and nivolumab. Of the 122 patients, nine $(7 \%)$ had thyroid dysfunction secondary to the treatment. Although this was not statistically significant, the patients who developed thyroid dysfunction were younger than those who remained euthyroid $(58.1 \pm 14.9$ years vs. $65.8 \pm 11.9$ years, $p=0.07)$. Female gender distribution was similar in both groups (55.6\% vs. $39.8 \%, p=0.35)$, as it was the proportion of patients with clinical stage 4 disease.

Non-small cell lung cancer was the most common neoplasm in patients without thyroiditis, while melanoma was the predominant tumor in patients with thyroid dysfunction. The proportion of patients who received each type of $\mathrm{ICl}$ was similar in both groups (Fig. 1). Of the group of patients who developed thyroid disease, five received treatment with pembrolizumab, two received nivolumab, and two, ipilimumab (one of them in combination with nivolumab). Table 1 compares the characteristics of patients with thyroid dysfunction with those of patients without this complication.

Prior to treatment initiation, all patients had normal thyroid function tests, with median baseline TSH of 1.77 (0.3-4.2) $\mu \mathrm{IU} / \mathrm{mL}$. Thyroid dysfunction occurred in a median of four cycles and 63 days after treatment was started; however, none of the patients required discontinuation of the drug. Of the nine patients, only

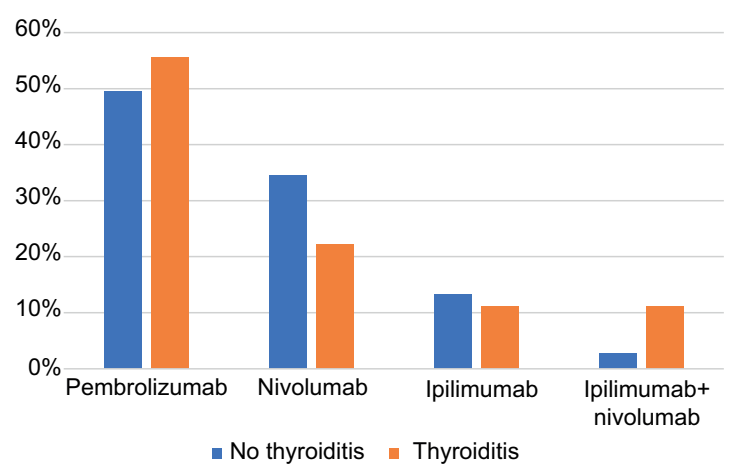

Figure 1. Patients with malignant neoplasms who developed or not thyroiditis secondary to the treatment with immune checkpoint inhibitors $(n=122)$.

Table 1. Baseline characteristics of $\mathbf{1 2 2}$ patients who received immunotherapy from January 2014 to December 2017

\begin{tabular}{|c|c|c|c|c|c|}
\hline Baseline characteristic & \multicolumn{2}{|c|}{$\begin{array}{l}\text { Thyroiditis } \\
\qquad(\mathrm{n}=9)\end{array}$} & \multicolumn{2}{|c|}{$\begin{array}{l}\text { No thyroiditis } \\
(n=113)\end{array}$} & p \\
\hline \multirow[t]{2}{*}{ Age $($ mean $\pm S D)$} & \multicolumn{2}{|c|}{$58.1 \pm 14.9$} & \multicolumn{2}{|c|}{$65.8 \pm 11.9$} & \multirow[t]{2}{*}{0.07} \\
\hline & $\mathrm{n}$ & $\%$ & $\mathrm{n}$ & $\%$ & \\
\hline Male gender & 4 & 44.4 & 68 & 60.2 & 0.35 \\
\hline $\begin{array}{l}\text { ECOG performance } \\
\text { status } \\
0 \\
1 \\
2 \\
3\end{array}$ & $\begin{array}{l}2 \\
4 \\
3 \\
0\end{array}$ & $\begin{array}{c}22.2 \\
44.4 \\
33.3 \\
0\end{array}$ & $\begin{array}{l}13 \\
36 \\
42 \\
22\end{array}$ & $\begin{array}{l}11.5 \\
31.9 \\
37.2 \\
19.5\end{array}$ & $\begin{array}{l}0.39 \\
\text { Ref. } \\
0.9 \\
0.8 \\
0.3\end{array}$ \\
\hline $\begin{array}{l}\text { Primary tumor } \\
\text { Lung } \\
\text { Melanoma } \\
\text { Bladder } \\
\text { Head and neck } \\
\text { Kidney } \\
\text { Other }\end{array}$ & $\begin{array}{l}1 \\
4 \\
1 \\
1 \\
1 \\
1\end{array}$ & $\begin{array}{l}11.1 \\
44.4 \\
11.1 \\
11.1 \\
11.1 \\
11.1\end{array}$ & $\begin{array}{c}44 \\
32 \\
13 \\
8 \\
6 \\
10\end{array}$ & $\begin{array}{l}39.9 \\
28.3 \\
11.5 \\
7.1 \\
5.3 \\
8.8\end{array}$ & $\begin{array}{l}0.68 \\
\text { Ref. } \\
0.78 \\
0.98 \\
0.78 \\
0.98 \\
0.4\end{array}$ \\
\hline $\begin{array}{c}\text { Stage } \\
\text { III } \\
\text { IV }\end{array}$ & $\begin{array}{l}0 \\
9\end{array}$ & $\begin{array}{c}0 \\
100\end{array}$ & $\begin{array}{c}8 \\
104\end{array}$ & $\begin{array}{c}7.1 \\
92.8\end{array}$ & $\begin{array}{c}0.4 \\
\text { Ref. } \\
0.99\end{array}$ \\
\hline $\begin{array}{l}\text { Treatment } \\
\text { Pembrolizumab } \\
\text { Ipilimumab } \\
\text { Nivolumab } \\
\text { Ipilimumab + nivolumab }\end{array}$ & $\begin{array}{l}5 \\
1 \\
2 \\
1\end{array}$ & $\begin{array}{l}55.5 \\
11.1 \\
22.2 \\
11.1\end{array}$ & $\begin{array}{c}56 \\
15 \\
39 \\
3\end{array}$ & $\begin{array}{c}49.5 \\
13.3 \\
34.5 \\
2.7\end{array}$ & $\begin{array}{c}0.65 \\
\text { Ref. } \\
0.99 \\
0.0005 \\
0.9\end{array}$ \\
\hline & \multicolumn{2}{|c|}{$\begin{array}{l}\text { Median } \\
\text { (IQR) }\end{array}$} & \multicolumn{2}{|c|}{$\begin{array}{l}\text { Median } \\
\text { (IQR) }\end{array}$} & \\
\hline Received cycles & \multicolumn{2}{|c|}{$5(4-16)$} & \multicolumn{2}{|c|}{$4(2-8)$} & 0.11 \\
\hline
\end{tabular}

ECOG $=$ Eastern Cooperative Oncology Group, $I Q R=$ interquartile range.

one initially presented with thyrotoxicosis, which later progressed to hypothyroidism. Median TSH at diagnosis was $22.58 \mu \mathrm{IU} / \mathrm{mL}$ (interquartile range 
$[\mathrm{IQR}]=22.58-86.69$ ), with a maximum of $233 \mu \mathrm{lU} / \mathrm{mL}$, and median FT4 was $0.5 \mathrm{ng} / \mathrm{dL}$ (IQR = 0.4-0.9). Anti-thyroid peroxidase and anti-thyroglobulin antibodies were measured in four patients, out of whom only half had positive results. Of the nine patients, three had mild disease (grade 1); three, moderate disease (grade 2) and three, severe disease (grade 3). At follow-up conclusion, survival in the group of patients with thyroiditis was $55 \%$, while only $38 \%$ of those without thyroid dysfunction survived; however, this relationship was not statistically significant. Eight of the nine patients received permanent replacement therapy with levothyroxine, with a median follow-up of three months (IQR $=1.25-3.75)$ and a median dose of $112.5 \mu \mathrm{g}(\mathrm{IQR}=81-168)$. The prevalence of thyroiditis during the study period for this population was $7 \%$, whereas an incidence of $21.4 \%$ patients/month was estimated.

\section{Discussion}

This is the first study of thyroiditis secondary to the use of immunotherapy in the Mexican population. ICls represent a new hope for patients with metastatic tumors, given that they significantly increase survival. ${ }^{13,14}$ These drugs are monoclonal antibodies that selectively target molecules that regulate the immune response and maintain homeostasis. The main targets of these antibodies are CTLA-4 (ipilumimab), PD-1 (nivolumab and pembrolizumab) and its ligand, PD-L1 (atezolizumab, avelumab and durvalumab)..$^{15}$ Inhibition of these molecules leads to excessive activation of the immune system, which while being useful for eliminating tumor cells, also causes self-tolerance mechanisms disruption, which leads to the development of autoimmune phenomena. ${ }^{16}$ Endocrine organs, especially the thyroid gland (but also the pituitary, pancreas and adrenal glands), are particularly susceptible to this phenomenon. ${ }^{17}$ The use of ICls, which are drugs that have been useful in the treatment of malignant neoplasms, has increased in recent years, therefore, the presence of treatment-associated endocrinopathy will be an increasingly common problem.

The incidence of autoimmune endocrinopathies associated with the treatment with $\mathrm{ICls}$ in patients with solid tumors is variable. The incidence of hypophysitis has been reported to be 9 to $17 \%$ in patients treated with ipilimumab, while thyroiditis is more common: it is observed in 15 to $30 \%$ of cases, depending on the $\mathrm{ICl}$ that is used..$^{18}$ Thyroid dysfunction was reported in one series in 29 out of 126 patients (23\%) who received ipilimumab as monotherapy, as well as in 18 out of 46 (39\%) patients on treatment with pembrolizumab or nivolumab. ${ }^{19}$ In another series, out of $177 \mathrm{pa}$ tients with metastatic melanoma, 24 (14\%) developed thyroid dysfunction. ${ }^{20}$ Prevalence in our study was $7 \%$, and incidence was $21.4 \%$ patients/month, which is lower than previously reported; however, our study includes patients with different types of solid tumors, not only melanoma. Our study shows similar results to those of a recent meta-analysis that included 7,551 patients and that reported an incidence of $6.6 \%$, with higher risk in patients who received combined treatment with anti-CTLA-4 and anti-PD1. ${ }^{21}$

The pathophysiology of $\mathrm{ICl}$ treatment-related thyroiditis is mainly inflammatory and destructive, which is why it occurs as an initial thyrotoxic phase secondary to the release of preformed thyroid hormones, although this phase is usually mild and normally goes unnoticed. ${ }^{22}$ Subsequently, a phase of hypothyroidism occurs, which in some cases returns to the euthyroid state. ${ }^{23}$ In our series, eight of the nine patients developed hypothyroidism with variable TSH elevations, from a minimal elevation to up to $200 \mu \mathrm{IU} / \mathrm{mL}$. Only one patient presented with subclinical hyperthyroidism that did not require medical treatment and weeks later evolved to the hypothyroid phase. This finding contrasts with data from other series, in which the hyperthyroidism phase occurred in more than half the cases.

Clinical presentation and severity of the condition are highly variable, in most cases with mild to moderate symptoms. ${ }^{24}$ Two thirds of our patients had grade 1 or 2 disease, while only in one were severe symptoms observed. Although it is not a common observation, cases of Graves' disease induced by the treatment with ICls have also been reported. ${ }^{25}$ Similar to findings in previous studies, anti-thyroid antibodies (anti-thyroid peroxidase and anti-thyroglobulin) were positive in half the patients in whom the measurement was carried out. ${ }^{26}$ According to findings reported in the literature, thyroiditis secondary to ICls was diagnosed in a median of 63 days after treatment was started. ${ }^{27}$ During follow-up, all patients remained hypothyroid and required levothyroxine stable doses. Thyroid function recovery was not documented in any patient.

\section{Conclusions}

This is the first analysis to evaluate the incidence and clinical characteristics of ICl-related thyroiditis in Latin America; however, it is a retrospective study with a small number of cases, with the limitations this 
implies. The incidence and clinical behavior of thyroid dysfunction in Mexican patients who received treatment with ICls for solid tumors were similar to those reported in previous series; however, most cases occurred as hypothyroidism. Due to the destructive nature of this disease, the majority of patients did not return to the euthyroid state and required long-term replacement therapy. Thyroid function tests should be performed before starting treatment with ICls and prior to each cycle, in order to diagnose and treat these patients in a timely manner and avoid severe symptoms and quality of life limitations. ${ }^{28}$

\section{Conflict of interests}

The authors deny conflicts of interest.

\section{Funding}

None.

\section{Ethical disclosures}

Protection of human and animal subjects. The authors declare that no experiments were performed on humans or animals for this research.

Confidentiality of data. The authors declare that no patient data appear in this article.

Right to privacy and informed consent. The authors declare that no patient data appear in this article.

\section{References}

1. Leach DR, Krummel MF, Allison JP. Enhancement of antitumor immunity by CTLA-4 blockade. Science. 1996;271:1734-136.

2. Byun DJ, Wolchok JD, Rosenberg LM, Girotra M. Cancer immunotherapy - immune checkpoint blockade and associated endocrinopathies. Nat Rev Endocrinol. 2017;13:195-207.

3. Brahmer JR, Lacchetti C, Schneider BJ, Atkins MB, Brassil KJ, Caterino JM, et al. Management of immune-related adverse events in patients treated with immune checkpoint inhibitor therapy: American Society of Clinica Oncology Clinical Practice Guideline. J Clin Oncol. 2017;36:1714-1768.

4. Dine J, Gordon R, Shames Y, Kasler MK, Barton-Burke M. Immune checkpoint inhibitors: an innovation in immunotherapy for the treatment and management of patients with cancer. Asia Pac J Oncol Nurs. 2017;4:127-135.

5. Hodi FS, O'Day SJ, McDermott DF, Weber RW, Sosman JA, Haanen JB, et al. Improved survival with ipilimumab in patients with metastatic melanoma. N Engl J Med. 2010;363:711-723.
6. Villa NM, Farahmand A, Du L, Yeh MW, Smooke-Praw S, Ribas A, et al. Endocrinopathies with use of cancer immunotherapies. Clin Endocrinol. 2018;88:327-332.

7. Di Dalmazi G, Ippolito S, Lupi I, Caturegli P. Hypophysitis induced by immune checkpoint inhibitors: a 10-year assessment. Expert Rev Endocrinol Metab. 2019;14:381-398.

8. Ferrari SM, Fallahi P, Galetta F, Citi E, Benvenga S, Antonelli A. Thyroid disorders induced by checkpoint inhibitors. Rev Endocr Metab Disord. 2018;19:325-333.

9. Castinetti F, Albarel F, Archambeaud F, Bertherat J, Bouillet B, Buffier P, et al. French Endocrine Society Guidance on endocrine side effects of immunotherapy. Endocr Relat Cancer. 2019;26:G1-G18.

10. Seth R, Messersmith H, Kaur V, Kirkwood JM, Kudchadkar R, McQuade JL, et al. Systemic therapy for melanoma: ASCO Guideline. J Clin Oncol. 2020;38:3947-3970.

11. Hanna N, Johnson D, Temin S, Baker S, Brahmer J, Elis PM, et al. Systemic therapy for stage IV non-small-cell lung cancer: American Society of Clinical Oncology Clinical Practice Guideline Update. J Clin Oncol. 2017; 35:3484-3515.

12. Common Terminology Criteria for Adverse Events (CTCAE) version 5.0. USA: U.S. Department of Health and Human Services/National Institutes of Health/National Cancer Institute; 2017

13. Larkin J, Chiarion』Sileni V, Gonzalez R, Grob JJ, Cowey CL, Lao CD, et al. Combined nivolumab and ipilimumab or monotherapy in untreated melanoma. N Engl J Med. 2015;373:23ロ34.

14. Postow MA, Callahan MK, Wolchok JD. Immune checkpoint blockade in cancer therapy. J Clin Oncol. 2015;33:1974-1982.

15. La-Beck NM, Jean GW, Huynh C, Alzghari SK, Lowe DB. Immune checkpoint inhibitors: new insights and current place in cancer therapy. Pharmacotherapy. 2015;35:963-976.

16. Buchbinder EI, Desai A. CTLA-4 and PD-1 pathways: similarities, differences, and implications of their inhibition. Am J Clin Oncol. 2016;39:98-106.

17. Ntali G, Kassi E, Alevizaki M. Endocrine sequelae of immune checkpoint inhibitors. Hormones (Athens). 2017;16:341-350.

18. Chang L, Barroso-Sousa, Tolaney, R, Hodi S, Kaiser U, Min L. Endocrine toxicity of cancer immunotherapy targeting immune checkpoints. Endocr Rev. 2019;40:17-65.

19. Morganstein D, Lai Z, Spain L, Diem S, Levine D, Mace C, et al. Thyroid abnormalities following the use of cytotoxic Tulymphocyte antigen $\square$ and programmed death receptor protein 1 inhibitors in the treatment of melanoma. Clin Endocrinol. 2017;86:614-620.

20. Scott ES, Long GV, Guminski A, Clifton-Bligh RJ, Menzies AM, Tsang $\mathrm{VH}$. The spectrum, incidence, kinetics and management of endocrinopathies with immune checkpoint inhibitors for metastatic melanoma. Eur J Endocrinol. 2018:178:175-182.

21. Barroso-Sousa R, Barry WT, Garrido-Castro A, Pode, FS, Min L, Quero IE, et al. Incidence of endocrine dysfunction following the use of different immune checkpoint inhibitor regimens: a systematic review and meta-analysis. JAMA Oncol. 2018:4:173-182.

22. Lee H, Hodi FS, Giobbie-Hurder A, Ott PA, Buchbinder El, et al. Characterization of thyroid disorders in patients receiving immune checkpoint inhibition therapy. Cancer Immunol Res. 2017:5:1133-1140.

23. Mishima Y, Fukaishi T, Inase N, Isogai S. Nivolumab-induced hypophysitis, secondary adrenal insufficiency and destructive thyroiditis in a patient with lung adenocarcinoma. Intern Med. 2019;58:693-697.

24. Mace C, Diem S, Gore M, Larkin J, Morganstein D. Thyroid abnormalities during anti-PD1 cancer immunotherapy. Endocrine Abstracts. 2015; 38:443

25. Azmat U, Liebner D, Joehlin-Price A, Agrawal A, Nabhan F. Treatment of ipilimumab induced Graves' disease in a patient with metastatic melanoma. Case Rep Endocrinol. 2016;2016:2087525.

26. Varricchi G, Loffredo S, Marone G, Modestino L, Fallahi P, Ferrari SM, et al. The immune landscape of thyroid cancer in the context of immune checkpoint inhibition. Int J Mol Sci. 2019;20:3934.

27. Guaraí F, La Selva R, Xamã MT, D'Angelo V, Gorin D, Fava P, et al. Characterization and implications of thyroid dysfunction induced by immune checkpoint inhibitors in real-life clinical practice: a long-term prospective study from a referral institution. J Endocrinol Invest. 2018;41:549-556.

28. Spain L, Diem S, Larkin J. Management of toxicities of immune checkpoint inhibitors. Cancer Treat Rev. 2016;44:51-60. 